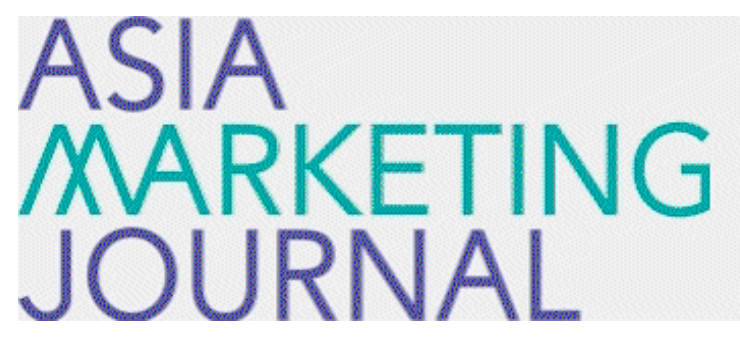

ASIA MARKETING JOURNAL

Volume 11 | Issue 3

Article 8

10-30-2009

\title{
기아자동차 SOUL의 혁신적인 제품전략
}

Doo-Hee Lee

Jong-Ho Lee

Ki Heung Jeon

Follow this and additional works at: https://amj.kma.re.kr/journal

Part of the Marketing Commons

\section{Recommended Citation}

Lee, Doo-Hee; Lee, Jong-Ho; and Jeon, Ki Heung (2009) "기아자동차 SOUL의 혁신적인 제품전략," Asia Marketing Journal: Vol. 11 : Iss. 3 , Article 8.

Available at: https://doi.org/10.53728/2765-6500.1398

This Article is brought to you for free and open access by Asia Marketing Journal. It has been accepted for inclusion in Asia Marketing Journal by an authorized editor of Asia Marketing Journal. 


\section{기아자동차 SOUL의 혁신적인 제품전략 \\ - 소비자의 soul을 움직이다 -}

\section{Innovative Product Strategy of KIA SOUL \\ - Attract customers' soul -}

이 두 희(Lee, Doo-Hee $)^{*}$

이 종 호(Lee, Jong-Ho)**

전 기 흥(Jeon, Ki Heung)***

본 사례는 Crossover Utility Vehicle (CUV)의 선구자인 기아자동차 SOUL이 혁신적인 제품전략을 통하여 어떻게 새로운 시장을 개척하였는지를 분석하고 있다. 지금까지 대부분의 자동차 제조업체들 은 전통적인 시장세분화 기준에 치중하여, 여러 소비자 계층들을 동시에 만족시킬 수 있는 신제품 개 발의 기회를 놓치고 있었다. 기아자동차 SOUL은 여러 소비자 계층을 만족시킬 수 있는 제품에 대한 기회를 포착하고, 기존 소비자 계층별 가치를 통합적으로 제공하여 새로운 시장을 열었다. 본 사례는 포화상태에 있는 자동차 산업에서 혁신적인 제품전략을 통해 신시장을 개척하는 과정을 잘 보여주고 있다. 기아자동차 SOUL의 혁신적 제품전략을 크게 디자인 혁신, CUV 시장 개척, 고객을 위한 맞춤 서비스 제공, 그리고 기능 혁신의 4 가지 축으로 설명하고 있다. 기아자동차 SOUL의 혁신적인 제품 전략은 블루오션 개척을 계획하고 있는 많은 기업에게 의미 있는 시사점을 제공해 준다.

핵심개념: 혁신적인 제품전략, 디자인 경영, 블루오션

\section{I. 서 론}

기아 자동차는 2000년 이후 국내 자동차 시장 에서 점점 시장 점유율이 떨어지는 위기를 맞

고려대학교 경영학과 교수(dhlee@korea.ac.kr)

** 고려대학교 경영학과 조교수(jongholee@korea.ac.kr)

*** 전주대학교 경영학과 부교수(khjeon@ jj.ac.kr)
게 되었다. 2000년 초반에는 시장점유율이 $20 \%$ 후반 대였으나, 지속적으로 감소하여 $20 \%$ 초반 까지 떨어지게 됨으로써(〈그림 1〉 참고), 기아 자동차의 경영진들은 이러한 시장 점유율 하향 세를 극복할 전략적 반전을 꾀하고자 하였다. 
시장 점유율 하락 원인을 알아보기 위한 자체 적인 소비자 의식 조사 결과, 소비자들은 기 아자동차의 품질을 상대적으로 저평가하고 있 다는 것을 알 수 있었다. Strategy $\operatorname{Clock}(\mathrm{C}$. Bowman and D. Faulkner, 1990)을 이용한 분 석은 경쟁사 제품과 비교하여 자사의 제품이 지닌 가격 대비 강점 및 약점을 파악함으로써 자사 제품이 어떠한 전략적 자세를 취할 지 알 려줄 수 있는 지침이 될 수 있으며, 분석 결과 당시 기아자동차의 이미지는 low price / low added value에 머무르고 있었으며 이러한 소비 자 의식을 변화시키기 위한 적극적인 노력이 필요하다는 것을 알 수 있었다. 또한 SOUL이 앞으로 취해야 할 방향은 Hybrid, 즉 가격 대비 상대적으로 높은 가치를 줄 수 있는 제품으로 인식되도록 해야 함을 알 수 있었다(〈그림 2〉 참고).

적극적인 변화를 위한 노력의 일환으로 기아 자동차 측에서 선택한 것은 '디자인 경영'이었 다. 정의선 기아자동차 사장은 2005년 부임하자
마자 ‘디자인 경영’을 주문했다. 현대자동차와 같은 엔진과 차체를 쓰는 기아자동차가 디자인 으로 차별화를 하지 않고서는 판매력과 생산성 에서 뒤처지므로 흑자를 내기 어렵다는 판단에 서였다. 하지만 현대 - 기아 통합 디자인연구소 는 좀처럼 변화를 보이지 못하였으며, 기아자동 차 디자인 담당자들 사이에서는 '현대자동차에 겐 이길 수 없다'는 패배의식도 팽배하였다. 이 와 같은 상황에서 정의선 사장은 아우디. 폭스 바겐의 수석 디자이너로 유럽에서 손꼽히는 자 동차 디자이너인 피터 슈라이어(Peter Schreyer) 를 디자인 총괄 부사장으로 영입하였고, 또한 디 자인 조직을 현대자동차에서 분리하게 하였다.

기아자동차는 디자인 혁신을 통한 차별화를 꾀하고자 하였으며, 그 후 출시된 모하비, 포르 테, 로체, SOUL 등은 혁신적인 디자인이라는 평가를 받게 되었다. 이들 중 SOUL은 $\mathrm{COOL}$ $\& \mathrm{COSMO}$, 즉 '유행에 민감한 세대를 위해 도 시적이고 활동적인 차'란 제품 컨셉으로 개발에 착수되어 대중에 선보인 후 세계 3 대 디자인상

\section{〈그림 1〉기아자동차 $M / S$ 판매 추이}

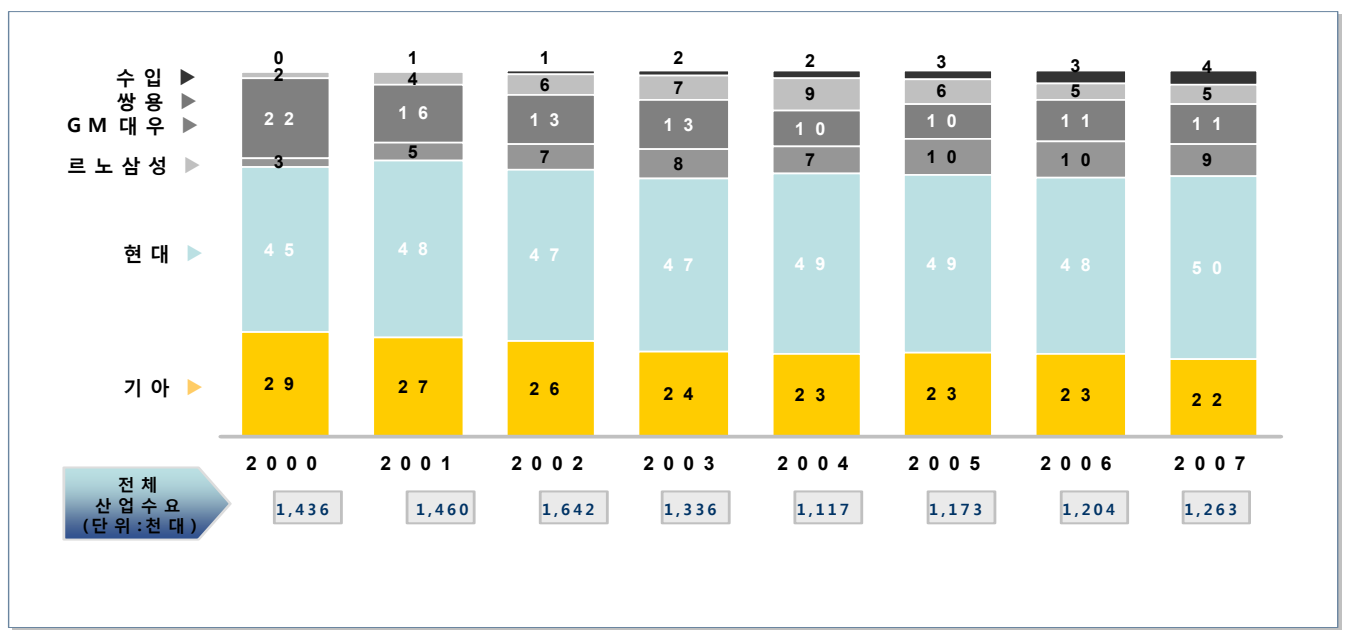


〈그림 2〉 Strategy Clock

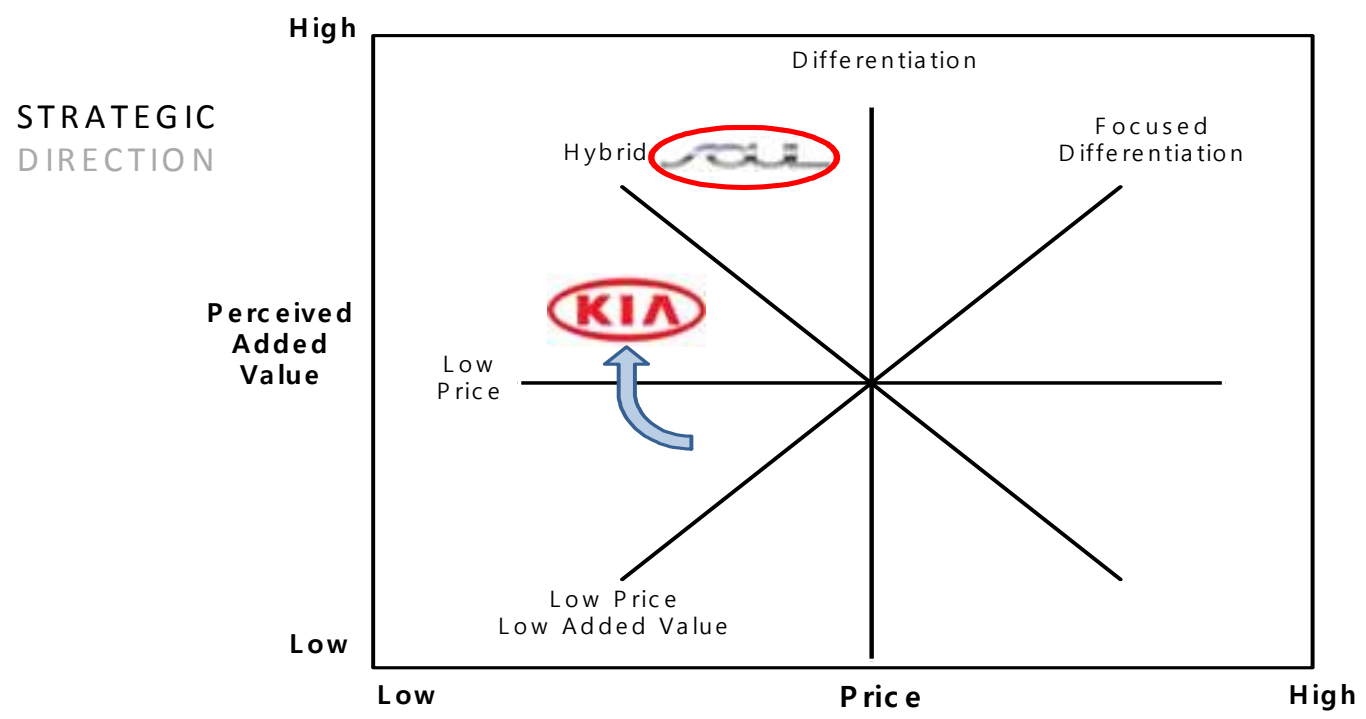

인 2009 레드닷 디자인 어워드(Reddot Design Award Honorable Mention 2009) 및 미국 워즈 오토월드(Ward's Autoworld) 선정 2009 올해의 인테리어 상 등 디자인 관련 상뿐만 아니라, 미 국 고속도로 안전보험 협회의 안전도 평가에서 도 최고점을 받는 등 국내외 각종 언론 및 대 중으로부터 호평을 받고 있다. SOUL은 기아자 동차의 디자인 경영의 성공적 결실로서, 기업브 랜드의 차별적 아이덴티티 형성에 기여하고 나 아가 국내 CUV(Crossover Utility Vehicle) 신 시장 선점을 통한 성장기반의 강화라는 목적 아래 전략적 차원에서 치밀하게 개발되었다. 구 체적으로 SOUL이 어떠한 제품전략을 바탕으로 시장에 출시되게 되었는지 살펴보도록 한다.

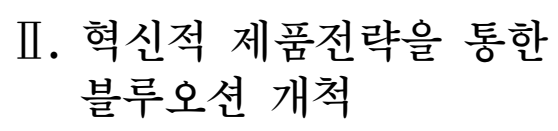

블루오션 전략은 기존의 전통적 입장과는 달 리 새로운 시장 창출에 초점을 맞추고 있다. 기 존 시장 내에서 경쟁자들을 견제하는데 초점을 맞추고 있지 않으며, 대체적인 역할을 할 수 있는 새롭게 창출된 시장(across substitute industries) 을 통한 재화 및 서비스의 제공은 기존 소비자 들의 기능적, 정서적 욕구(across functional and emotional appeal)를 충족시켜주는 역할을 하게 된다. 성공적인 블루오션 시장 창출을 위해서는 혁신적인 제품 및 서비스를 기반으로 혁신적 가치와 함께 성공적인 비즈니스 모델이 형성되 어야 한다. 그러나 이러한 제품과 서비스는 기 존 소비자들의 니즈와 완전히 동떨어진 가치들 을(value jump) 제공함으로써 가능하다기 보다 는, 지금까지 간과될 수 있었던 소비자들의 니 
즈를 충족시켜 주며 기존의 제품과 서비스를 대체하는(across complementary offerings) 역할 을 함으로써 혁신적이라 할 수 있다. 이와 같은 혁신적 제품 및 서비스는 특정 고객만이 아닌, 다양한 소비자 계층(across strategic group)에 어필할 수 있으며 또한 기존의 고객 외에 새로 운 고객(across chain of buyers)을 불러들일 수 있는 역할을 하기도 한다. 블루오션 시장이 창 출된 경우 이러한 시장은 단기간 트랜드로 인 기를 얻었다가 소멸된다기 보다는, 시간과 트랜 드(across time \& trends)를 초월할 가능성이 높다(Kim \& Mauborge, 2005a, 2005b).

$\operatorname{Kim} \&$ Mauborge(2005a, 2005b)에 의해 소 개되고 있는 블루오션 전략의 많은 사례들을 살펴보면 신제품 개발 전략과 깊은 연관이 있 음을 알 수 있다. 또한 이러한 신제품들은 기 존의 다른 제품들과는 달리 가치 혁신(Value Innovation)을 추구한 결과물이라 할 수 있다. 기아자동차 SOUL의 경우에도 다음과 같은 측 면에서 가치 혁신을 통한 혁신적 제품 및 서비 스를 기반으로 하여 블루오션 시장을 개척한 경우라 할 수 있다. 기존에 출시된 어떠한 차종 과도 다른 차별적 외관인 박스카 형태의 $\mathrm{CUV}$ 차량으로 개발함으로써 디자인 측면에서 혁신 적인 가치를 소비자들에게 제공할 수 있었으며, 튜닝전문 커스터마이징 서비스 브랜드 TUON 을 출시함으로써 기존에는 제공되지 않았던 새 롭고 혁신적인 서비스 제공을 통해 가치 혁신 을 이룬 것이라 할 수 있다. SOUL은 기존 차 량과의 단순 경쟁을 위한 목적으로 한 차량 이 라기보다는 새로운 차종 시장을 개척하고 기존 에 국내에 존재하지 않았던 새로운 서비스를 제공하는, 일종의 블루오션 시장을 개척한 것이
라 할 수 있다는 것이다.

특히 디자인 혁신은 차별화를 통해 기업의 매출 및 수익 증진에 기여하며, 동시에 브랜드 이미지를 제고시킴으로써 브랜드 가치 또한 증 대시키는 중요한 역할을 한다. 영국 디자인 협회 의 조사에 다르면 디자인 선도 기업(Design Ledcompany)의 주가는 1994년에는 FTSE(Financial Times Stock Exchange) 100대 기업과 유사한 수준이었으나 2007년에는 약 2배의 격차를 보 이는 것으로 드러났으며, 이러한 예는 디자인 혁신이 기업의 실제 경제적 이익으로 연결됨을 보여주는 것이라 하겠다. 이와 같은 디자인 혁 신의 최우선 조건은 디자인 리더십이라 할 수 있으며, 최고 경영진 스스로 디자인에 대한 이 해를 바탕으로 직접 유능한 인재를 선발하고 창의적인 조직을 운영하여야 한다. 또한 디자인 책임자에게 많은 재량권을 부여하고, 다양한 배 경을 지닌 우수 인력 등이 함께 제품 개발에 뛰어들어야 하며, 기업의 이념과 전략에 부합하 는 일관된 디자인 철학이 수립되어야 한다(하 송, 2008). SOUL의 개발을 총 지휘한 정의선 사장의 노력도 이와 같은 맥락에서 디자인 리 더십을 가진 최고경영진의 성공적인 디자인 경 영의 예라 할 수 있을 것이다.

\section{SOUL 개발 시 고려사항}

\section{1 다양한 차급으로의 인식}

2002년 이후 승용차 시장은 증가 추세에 있으나 SUV(Sports Utility Vehicle) 및 MPV(Multi 
Purpose Vehicle) 시장은 감소 추세에 있었다 (〈그림 3〉참고). 단계적인 세제 혜택 및 유가 혜택이 축소 됨에 따라 경제성을 이유로 SUV, $\mathrm{MPV}$ 를 구입하는 소비자들은 줄어들게 되었으 나, 여전히 차량의 활용성을 고려해서 이들 차 종을 구입하는 소비자들이 존재하였다. 실용성 측면에서는 긍정적인 측면이 부각되더라도 차 종별 소비자 인식 조사 결과 해치백의 경우 짐 차와 같은 이미지로 고급스러운 이미지가 부족 하였으며, MPV의 경우 디자인 차별성이 부족 하게 느껴졌으며, SUV의 경우 승차감 및 정숙 성이 부족하다는 단점이 지적되었다. 이와 같은 시장 상황에서 SOUL은 외관상 특정 차급으로 규정되기 보다는 차별화되고 독특한 컨셉의 다 양한 차급으로 인식될 수 있는 차종으로 개발 하고자 하였다. 소비자들에 따라서 각각 승용차, $\mathrm{SUV}, \mathrm{MPV}$ 와 같이 인식할 수도 있으며, 이와 같은 차종에 포함되지 않는 새롭고 독특한 형 태의 차종으로 인식될 수 있도록 하고자 한 것 이다. 그러므로 SOUL은 CUV 차량으로 개발함 으로써 차급 간 수요 간섭을 막으며 차별화되
고 독특한 이미지로 보이고자 하였다.

\section{2 튜닝에 대한 소비자들의 니즈}

자체적인 조사 결과, 최근 소비자들은 휴대폰, 신발, 의류 등 다양한 품목에 대해 개성을 드러 낼 수 있도록 자체적으로 튜닝을 하고자 하는 트랜드를 확인하였다. 특히 차량 튜닝에 대해서 단순히 내/외장 디자인을 개선하여 개성을 드 러낸다는 차원을 넘어서서, 성능 업그레이드를 통해 운전 스타일에 맞게 기능을 변경함으로써 만족을 극대화하기 위한 수단으로 인식했다. 이 와 같은 트랜드는 20 30대 사이에서 남과 다 른 나를 표현하고자 하는 옥구는 증가하였으며, '미코노미(Meconomy)' 즉 웹을 비롯한 각종 기 술의 발달로 더 많은 표현과 생산의 능력을 갖 춘 개인이 과거 기업의 고유영역이었던 공급자 의 역할을 대체하면서 개인이 중심에 자리잡는 경제체제와 같은 맥락에서 개인이 생산과 소비 에 모두 참여하는 것에 익숙해졌기 때문이다 (김태우, 2008).

〈그림 3〉 국내 차급별 비중 (M/S)

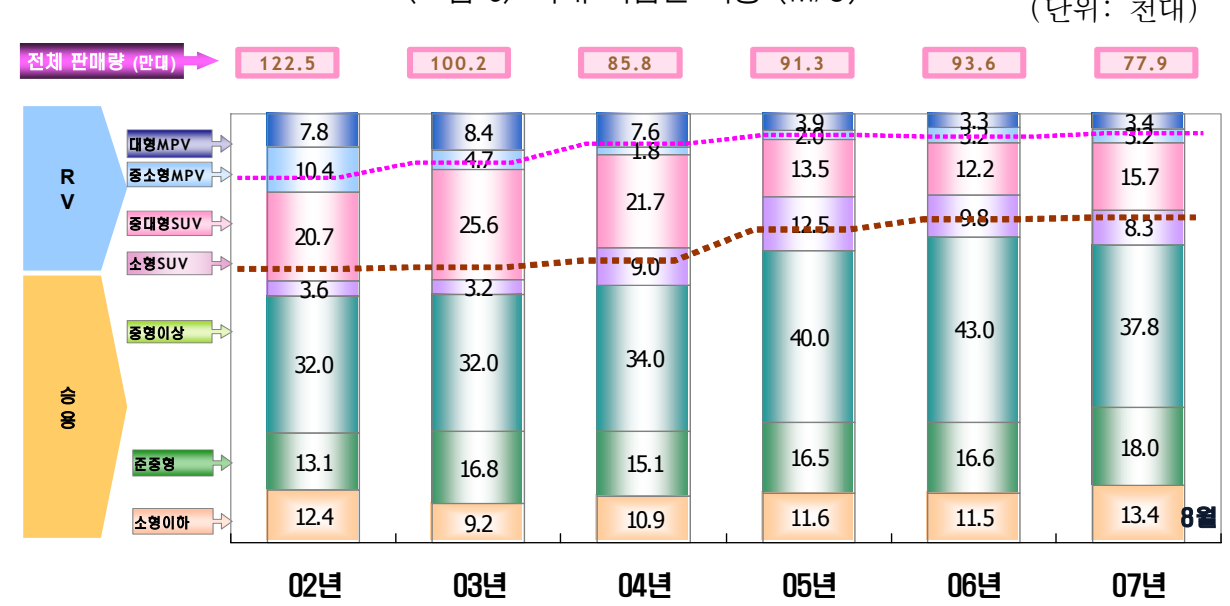


그러나 이와 같은 소비자층의 튜닝에 대한 니 즈를 충족시키기엔 국내 튜닝 부품, 서비스 제 공업체가 부족한 실정이며 전문적인 종합 튜닝 서비스 브랜드도 전무한 실정이었다. 그러므로 기아자동차는 이와 같은 소비자들의 튜닝트랜 드를 반영하여 튜닝 전문 커스터마이징 서비스 브랜드를 개발하고자 하였다. 튜닝 산업 자체의 잠재적 성장 전망도 굉장히 밝을 것으로 예상 되므로 튜닝전문 서비스를 제공하고자 하는 것 은 단순히 SOUL 소비자에 대한 서비스 강화 차원을 넘어서서 국내 튜닝전문브랜드를 통한 서비스 제공이라는 블루오션을 개척하는 것이 라 할 수 있다(〈그림 4〉참고).

\section{3 타겟 고객층인 '영트렌드세터(Young Trendsetter)'의 특성}

SOUL은 개성이 뚜렷하고 유행 및 트랜드에 민감한 '영 트랜드세터’를 타겟고객층으로 삼았 으므로, 혁신성과 즐거움(Innovative \& Fun)을 줄 수 있는 브랜드 개성을 가지도록 개발하고 자 하였다. 이들은 자신들이 만족 할만한 활동
을 하는데 아낌없이 투자하고, 집이나 차 등의 개인 생활공간을 다양한 장치와 시설로 꾸미고 자신의 삶을 표현하는데 적극적인 것으로 파악 되었다. 즉 SOUL의 타겟 고객층은 흔히 볼 수 없는 독특하고 혁신적인 스타일의 제품을 선호 하며, 새로운 트랜드의 수용성이 높은 얼리어댑 터 성향을 띨 것으로 예상되므로, 혁신성과 즐 거움을 줄 수 있는 제품으로 다가가는 것이 적 절한 전략인 것으로 파악된다. 그러므로 $\mathrm{SOUL}$ 을 개발하는 데 있어서 혁신성을 내포하는 것 은 필수적이라 할 수 있으며, 디자인, 서비스, 차종, 기술성 등 다양한 제품 속성에 있어서 혁 신성을 강조하여 제품을 개발하고자 하였다.

\section{SOUL의 혁신성}

\section{1 디자인 혁신성}

$\mathrm{SOUL}$ 은 디자인 측면에서 볼 때 기존에 국내 에서 출시되지 않았던 박스카 형태의 차별적

〈그림 4〉 국내외 튜닝 산업 현황
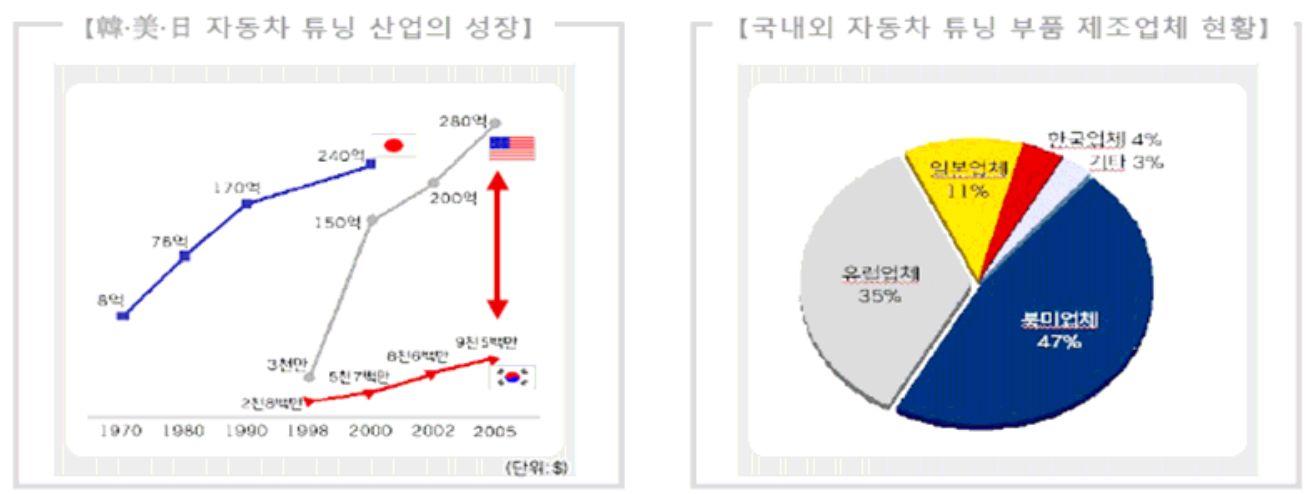
외관 디자인을 통해 소비자들의 눈길을 사로잡 고 있다. '젊은 감각의 신개념 CUV'로 개발한 다는 취지 아래 세단, SUV, 미니밴과 같이 서 로 다른 각각의 장점 및 차량 특성을 결합시켜 복합적인 컨셉을 띄고 있으나, 기존에 출시되었 던 타 경쟁사의 CUV와는 달리 더욱 개성적이 며 혁신적인 디자인의 CUV로 개발되었다. 수 입차종인 닛산의 큐브(CUBE) 및 도요타의 싸 이언 $\mathrm{xB}(\mathrm{Scion} \mathrm{xB})$ 와 외관상 닮은 꼴이라는 평 가들도 있으나, 좀 더 SUV이미지가 강하며 다 이나믹한이나믹한 캐릭터를 지녔으며 독특하고 혁신적인 디자인이라는 긍정적인 평가를 받고 있다. 피터 슈라이어가 SOUL 디자인의 핵심은, '지금까지의 관습을 거부하는 것'이라고 인터뷰 에서 밝힌 것처럼 SOUL의 디자인은 기존에 출 시된 여느 차종들과는 차별화에 성공한 것으로 평가된다.

외관에 대한 첫인상 선호도 조사에서 'SOUL > 스포티지 > i30> 카렌스> 프라이드' 순으로 긍 정적인 평가를 받았으며(〈그림 5〉 참고), 독특하 고 신선하며 미래지향적이며 긍정적이라는 이 미지가 강하다는 반응이 많았다. 특히 국내에서
보지 못한 독특하고 신선한 디자인으로 강한 인 상을 주고 있으므로, 기존 차량 대비 차별적이 고 독창적인 포지션을 선점할 수 있을 것으로 판단된다. 시장에 출시된 경쟁 차종들과 함께 이루어진 외관 이미지 조사에서도 다른 차종들 과는 달리 '혁신적인, 독특한, 도전적인'과 같은 평 가를 받고 있는 것으로 드러났다(〈그림 6〉 참고).

\section{2 국내 $\mathrm{CUV}$ 차종의 시초}

SOUL은 특정 차급으로 인식되기 보다는 다 양한 차급으로 인식될 수 있도록 하기 위해 세 단, $\mathrm{SUV}, \mathrm{MPV}$ 등의 특성 및 장점을 통합한 국내 CUV 차종의 시초라 할 수 있다. 개발 단 계에서 심층 면접을 통한 조사 결과, 측면에서 봤을 때 짐을 실을 수 있는 미니밴으로 느껴지 면서 SUV보다는 엔진 배기량이 낮다는 점에서 는 MPV로 인식되며, 차높이와 근육질의 디자 인이라는 점에서는 $\mathrm{SUV}$ 로 인식되며, 소형차 이미지의 차체와 실내 크기로 인해 해치백처럼 인식된다는 응답들이 나왔다(〈그림 7〉 참고). 즉 SOUL을 MPV(Multiple Purpose Vehicle)로

\section{〈그림 5〉 외관에 대한 첫인상 평가}

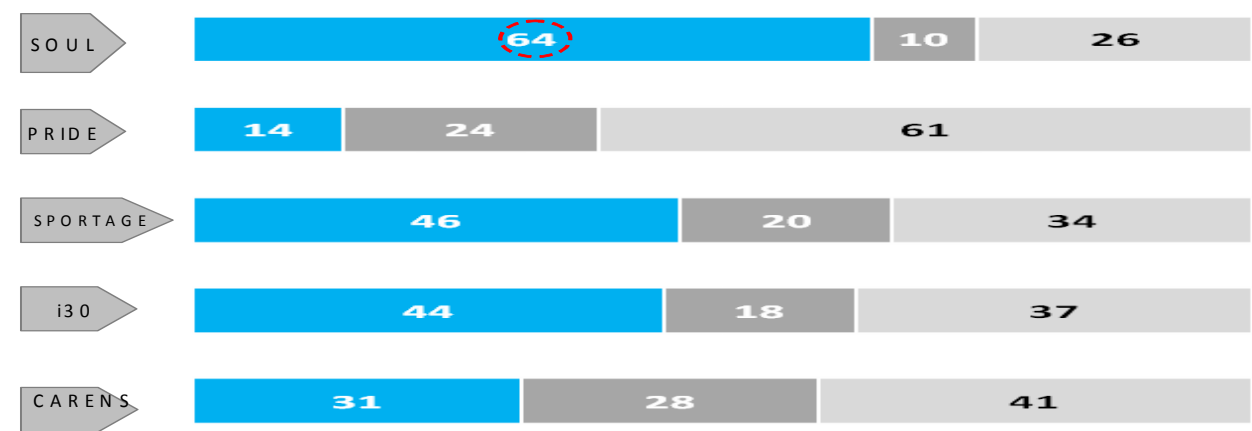

SOUL $>$ SPORTAGE $>$ I $30>$ CAREN S > PRIDE 
〈그림 6〉 외관 이미지 포지셔닝

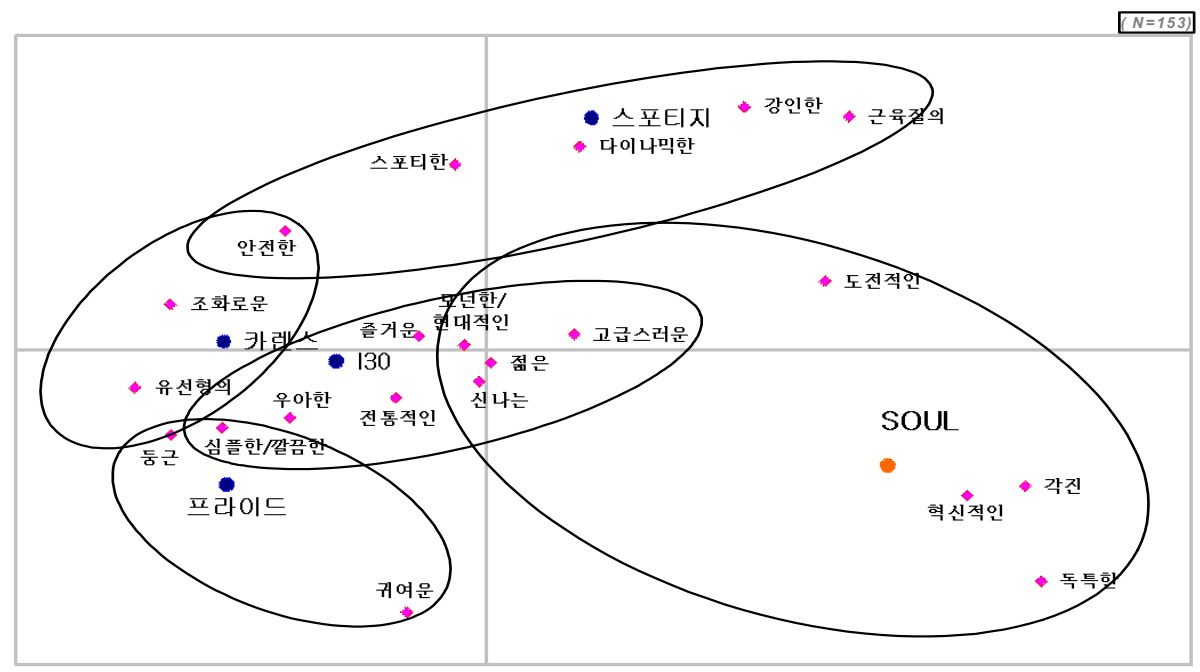

〈그림 7〉 SOUL에 대한 차급 인식 및 예상 경쟁차종

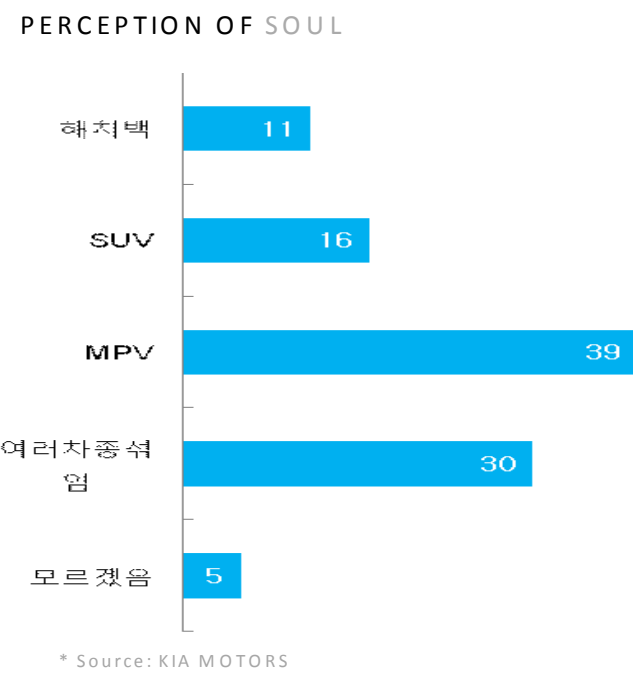

EXPECTED COM PETITORS

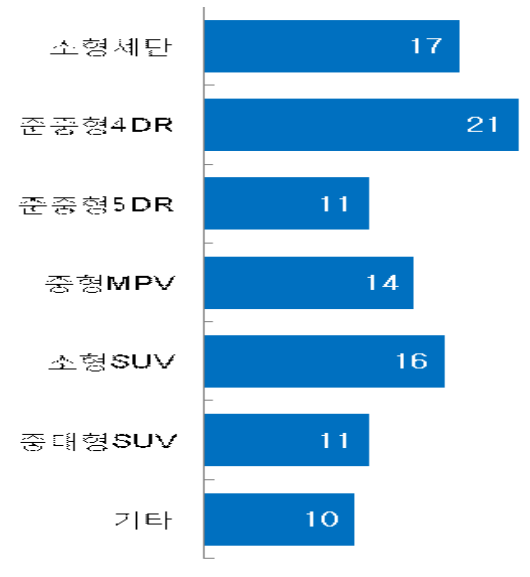

인식하는 비율이 높긴 했으나, 여러 차종의 특 형태의 다양한 차종과의 경쟁이 가능하며, 여러 성들을 다 연상시키게 하므로 $\mathrm{CUV}$ 차종으로 차종의 잠재 소비자들 또한 SOUL에 대해 구매 인식되는 비율이 높으며 이러한 차급 인식은 를 고려할 수 있다고 예상할 수 있다. $\mathrm{CUV}$ 차 개발 단계에서 제작진들의 의도가 잘 반영된 종 시장이라는 블루오션 시장을 형성한 것이라 것이라 할 수 있다. 또한 이와 같이 다양한 차 급으로 인식될 수 있으므로 세단, $\mathrm{MPV}, \mathrm{SUV}$ 할 수 있으며 이와 같은 시장 형성은 경쟁차량 에 의한 시장잠식이 적은 이점이 있다. 
〈그림 8〉 TUON의 패키지 서비스 분류

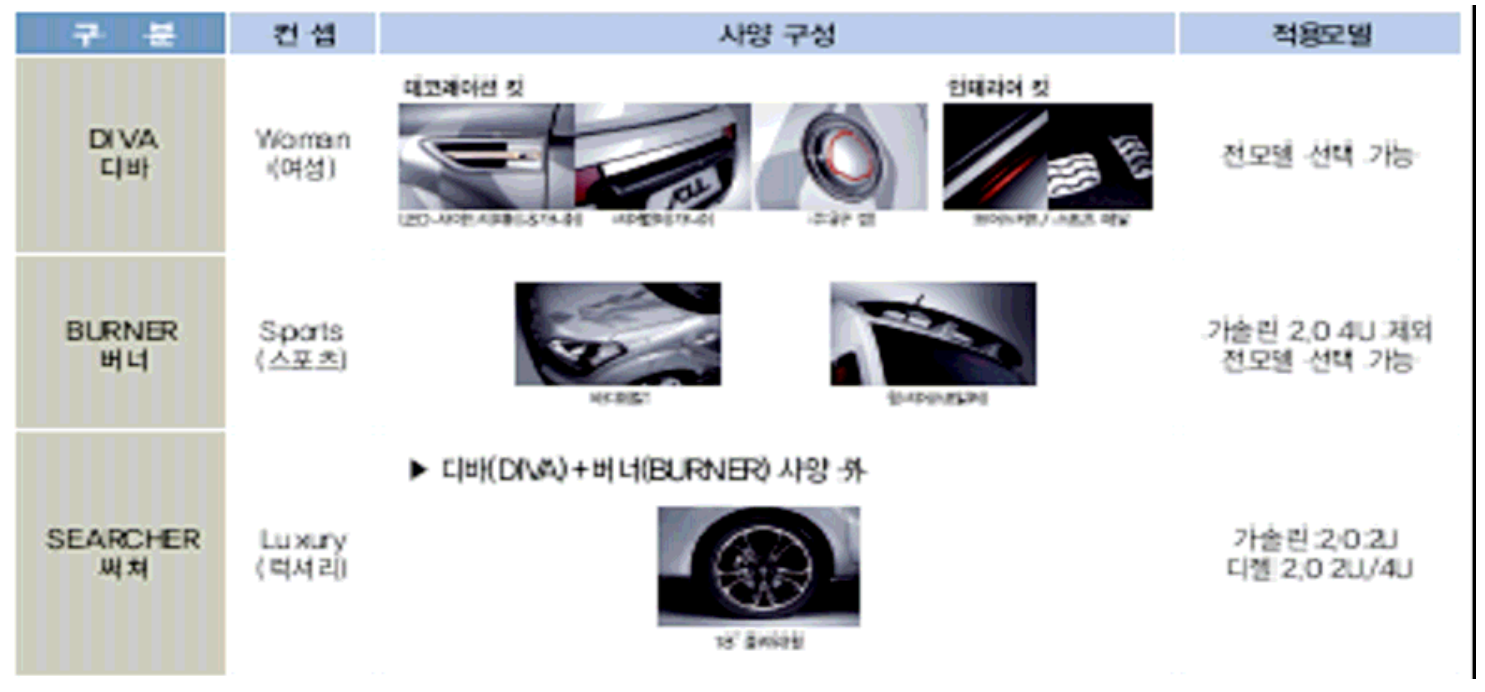

4.3 튜닝전문 커스터마이징서비스 브랜드 출시

국내 최초 튜닝전문 커스터마이징 서비스 브 랜드인 TUON을 SOUL과 동시에 출시함으로써 튜닝에 대한 소비자들의 니즈를 충족시키고자 하였다. 차량에 대한 전문적인 종합 튜닝서비스 수요는 증가하는데 비해 이와 같은 서비스를 제공하는 국내 경쟁메이커는 전무한 상황에서, 기아자동차의 튜닝전문 커스터마이징 서비스 브 랜드 출시는 혁신적인 것이라 할 수 있다.

일반적으로 튜닝서비스는 내/외장 스타일을 변경하는 '드레스업', 주행성능/출력을 증강하도 록 도와주기 위한 '튠업', 다양한 기능 개조를 위한 '기능업' 서비스가 있지만, TUON은 '드레 스업'에 중점을 두어 전문적인 이미지를 기본적 으로 보유하면서 흥미있고 즐거운 정서적 이미 지를 강조하여 차별화를 가져오고자 하였다. 바 디킷, 인테리어킷, 데코레이션킷, 18 인치 플라워
힐, 윙 스포일러, 바디데칼과 같이 엔진/트림별 $\mathrm{TUON}$ 의 개별 옵션이 운영되고 있으며, 각각의 개별 옵션들을 '여성, 스포츠, 럭셔리'와 같이 컨 셉에 따라서 스패셜 패키지로도 선택할 수 있 는 서비스를 제공하고 있다(〈그림 8〉 참고).

튜온이라는 네이밍 또한 'Tuning + On'의 조 합어로 지속적인 발전과 함께, “Tune Up the Optimistic Next'의 함축어로 튜닝의 새로운 패 러다임을 연다는 의미를 통해 튜닝을 통한 차 별적 이미지를 창출하고자 하는 브랜드 목표를 내포하고 있다. 또한 TUON, KIA, SOUL이라 는 브랜드 각각이 서로 간에 신뢰성, 개성, 전문 적인 이미지를 높임으로써, 상호 간 브랜드 시 너지 효과를 창출하고자 한다.

\section{4 기능적 혁신성}

SOUL은 외관 디자인 뿐만 아니라 내부 디자 인 및 기능성 측면에서도 기존의 차들과는 차 


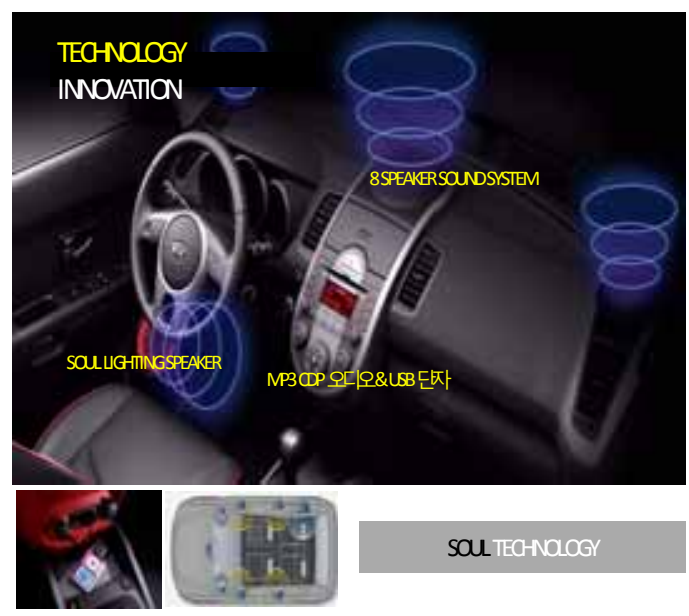

별적이고 혁신적이라 할 수 있다. 음악에 따라 프런트 스피커 내장 조명이 변화하는 라이팅 스피커, 어두운 곳에서 시트에 새겨진 SOUL 문자가 빛나는 라이팅 시트, 도킹 스테이션, 노 트북용 Power-Outlet, 후방 디스플레이 룸미러, 시트 구조를 다양하게 변경하여 아웃도어 활동 시 넉넉한 실내공간을 제공하는 것이 그 예라 할 수 있다(〈그림 9〉 참고). 이와 같은 신기술 적용은 차량 내부 공간을 생활의 중요한 거주 공간으로 여기며, 기능성을 중시하는 20 30대 타겟 고객인 영트렌드세터에게 강하게 소구할 수 있는 역할을 하고 있다.

\section{SOUL 출시 전략}

\section{1 시장세분화(Segmentation)}

시장 세분화 과정에서 각 차급별 소비자 집단

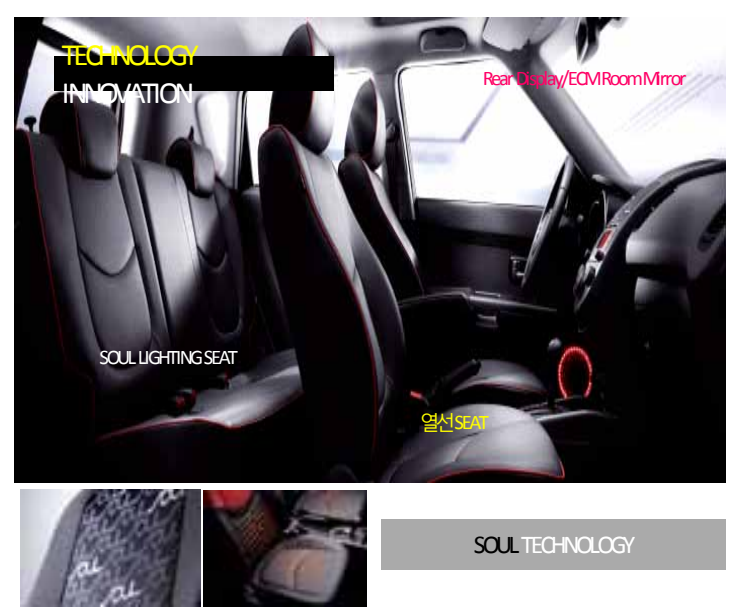

은 차량 선택시 주요하게 고려하는 요소들 즉, 성능(performance), 경제성(economy), 스타일 (style), 안전성(safety), 기능성(utility), showoff(개성표현), 공간성(spacious)들 중 주요하게 여기는 요소들의 차이에 따라서 다른 고객층으 로 구분하였다. 이들 중 $\mathrm{CUV}$ 컨셉을 가진 SOUL이 중점을 두는 고객은 '스타일과 활용성' 을 중시하는 고객들이다. 즉 자신들만의 개성표 현을 중시하고(Show-off), 차량의 내외관 스타 일 및 모델의 독특성 및 신선함을 중요하게 여 기며(Stylish), 차체 크기 및 차량 내부의 공간 성 및 화물 적재성(Spacious)를 중요하게 여기 는 고객층이라 할 수 있다(〈그림 10〉 참고).

\section{2 타겟팅(Targeting)}

SOUL은 독특한 개성과 상품성을 기반으로 다양한 차종과 경쟁구도를 형성하여 핵심 타겟 층 뿐만 아니라 폭넓은 세대로 소비 저변을 확 대하고자 하였다. 주타겟층인 20,30 대의 영트렌 


\section{SOUL SEGMENTATION}
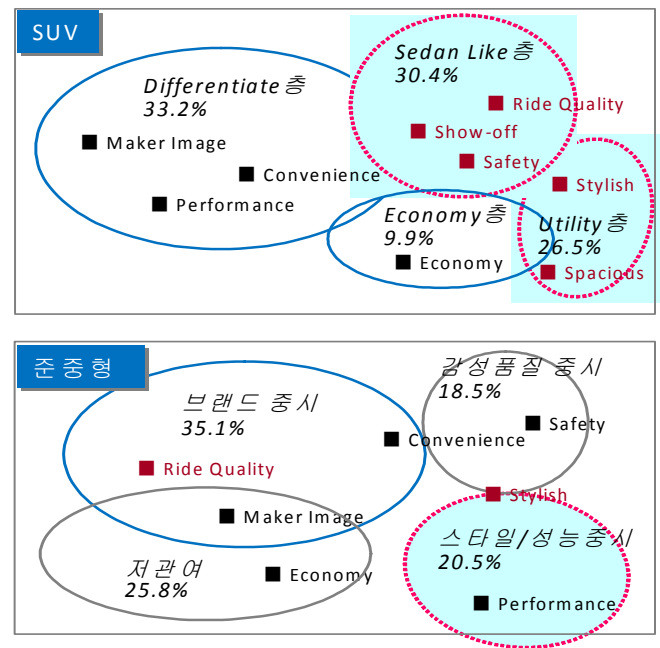

드세터들은 경제력이 있고 개성이 뚜렷한 것 이 주요특성이다. 인구통계학적으로는 20대 중 반에서 30 대 중반의 연령대에 월평균 소득이 300 500만원 정도이며, 미혼으로 사무직, 기술 직, 전문직, 대학생일 것으로 예상하였다. 라이 프 스타일 측면에서는 흔히 볼 수 없는 독특한 스타일의 제품을 선호하고 새로운 트랜드에 대 한 수용성이 높은 얼리어댑터(Early Adopter) 일 것으로 파악하였다. 서브타겟 고객층으로는 스타일과 개성을 중시하며 '마음이 젊은 중년 층'(Ageless Senior)으로 정하였다. 활동적인 야 외 활동을 선호하며, 나이에 구애받지 않고 젊 은 트렌드를 선호하는 중년층들이 서브타겟층 이라 할 수 있다.

\section{3 포지셔닝(Positioning)}

시장 및 타겟 분석에 근거하여 SOUL은 혁신
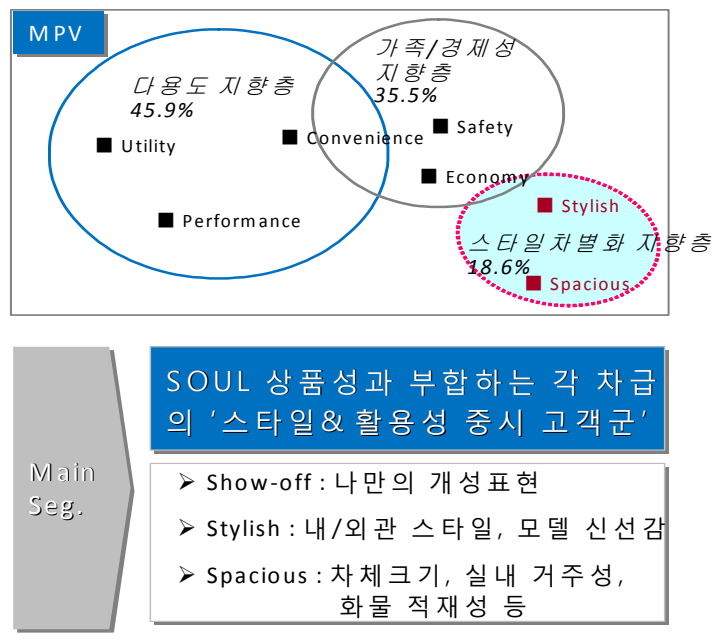

SOUL 상품성과 부합하는 각 차급

의 '스타일 \& 활용성 중시 고객군'

$>$ Show-off : 나만의 개성표현

$>$ Stylish : 내/외관 스타일, 모델 신선감

$>$ Spacious : 차체크기, 실내 거주성,

화물 적재성 등

성과 즐거움(Innovative \& Fun)을 줄 수 있는 브랜드 개성을 가지도록 개발하고자 하였다. 핵 심 브랜드 아이덴티티(Brand Identity)는 혁신성 (Innovative)이며, 확장된 브랜드 아이덴티티는 즐거움과 도전정신(Fun \& Challenging)이며 이와 같은 특성을 기반으로 경쟁차량과의 차별 적인 위치를 확고하게 하고자 하였다(〈그림 11〉 참고).

\section{4 마케팅 전략}

SOUL은 독특한 개성과 상품성을 기반으로 다양한 차종과 경쟁구도를 형성하여 핵심 타겟 층 뿐만 아니라 폭넓은 세대로 소비 저변을 확 대하고자 하였으므로, 마케팅 전략 또한 타겟 고객층에 따라 다르게 계획되었다. 주타겟층인 20 30대의 영트렌드세터들을 위해서는 즐거움 (SOUL of Fun) 및 도전(SOUL of Challenge) 


\section{SOUL POSITIONING}

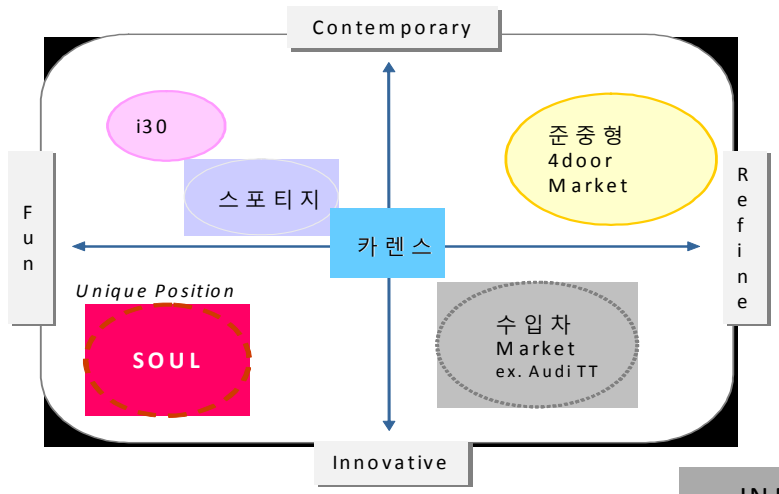

SOUL BRAND IDENTITY

$\sqrt{ }$ Core $\mathrm{BI}:$ Innovative

$\checkmark$ Extended $\mathrm{BI}:$ Fun, Challenging

Youth BI 및 新 Seg. 포지 셔닝을 통한

기 아의 Innovative / Challenging 강 조

INNOVATIVE, FUN \& CHALLENGING

과 관련된 마케팅 전략 지침이 세워졌으며, 서 관련된 마케팅 전략 지침들, 즉 다양한 프로모 브타겟 고객층인 스타일과 개성을 중시하는 중 션, 광고, 홍보, 전시, 이벤트를 통한 출시 전략 년층을 대상으로는 스타일(SOUL of Style)과 이 차별적으로 계획 및 추진되었다(〈표 1〉참고).

〈표 1〉SOUL의 타켓 별 마케팅 전략

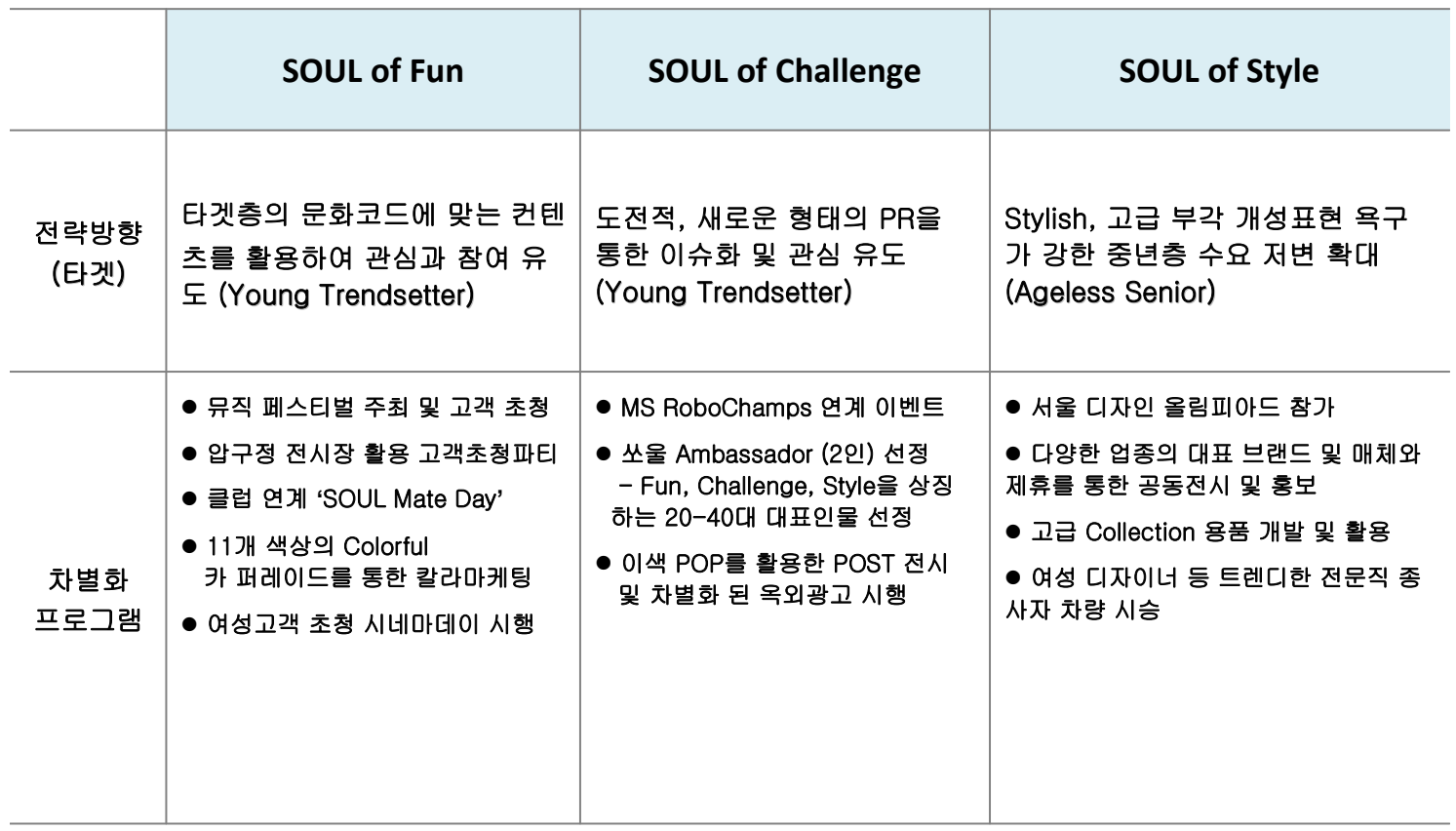




\section{SOUL 출시 후 반응 및 향후 방향}

기아자동차(주)는 SOUL 출시 이후에도 지속적 으로 제품 및 브랜드 관리에 심혈을 기울이고 있다. 출시 후 소비자들의 인식 조사 결과, SOUL의 이미지는 젊고 세련된 이미지로 비추 어졌으며, 커스터마이징 서비스가 구매에 긍정 적인 영향을 미친다고 응답한 경우가 상당히 높았다(매우 긍정적 $25.4 \%+$ 긍정적 $51.6 \%=$ 약 $77 \%)$.

또한 전체 응답자 중 $90 \%$ 가 SOUL이 기아 브랜드 이미지에 긍정적인 영향을 끼쳤다고 평 가한 것으로 나타났다. 긍정적인 이미지로 변화 를 가져온 요인들 중 디자인을 가장 중요한 요
인으로 뽑았다. 실제 차량을 구매한 소비자들의 경우에도 구매 사유에 대해 디자인을 가장 중 요한 요소로 꼽았다 $(35 \%)$. 이와 같은 반응은 SOUL을 출시함으로써 기아차 브랜드 전반에 대한 이미지 제고를 가져오고자 한다는 출시 당시의 목표에 부응하는 것이라 할 수 있다.

SOUL은 국내뿐만 아니라 미국 및 유럽 각국 에서 판매가 지속적으로 증가하며 호조를 보이 고 있다. 특히 미국의 경우 박스카(Box Car) 시장에서 4 월 이래 4 개월 연속 1 위에 올랐으며, 올해 누적판매량에서도 선두를 달리고 있는 쾌 거를 이루고 있다. 특히 인지도가 높은 닛산 큐 브가 미국시장에서 본격 판매되기 시작한 6 월 이후 쏘울의 판매량이 줄어들 것이라는 예상을 뒤엎고, 1 위를 고수하는 이변을 일으키고 있다. 쏘울은 미국시장 판매 가격이 약 1 만 4 천 달러

〈그림 12〉미국 SOUL 매출 추이

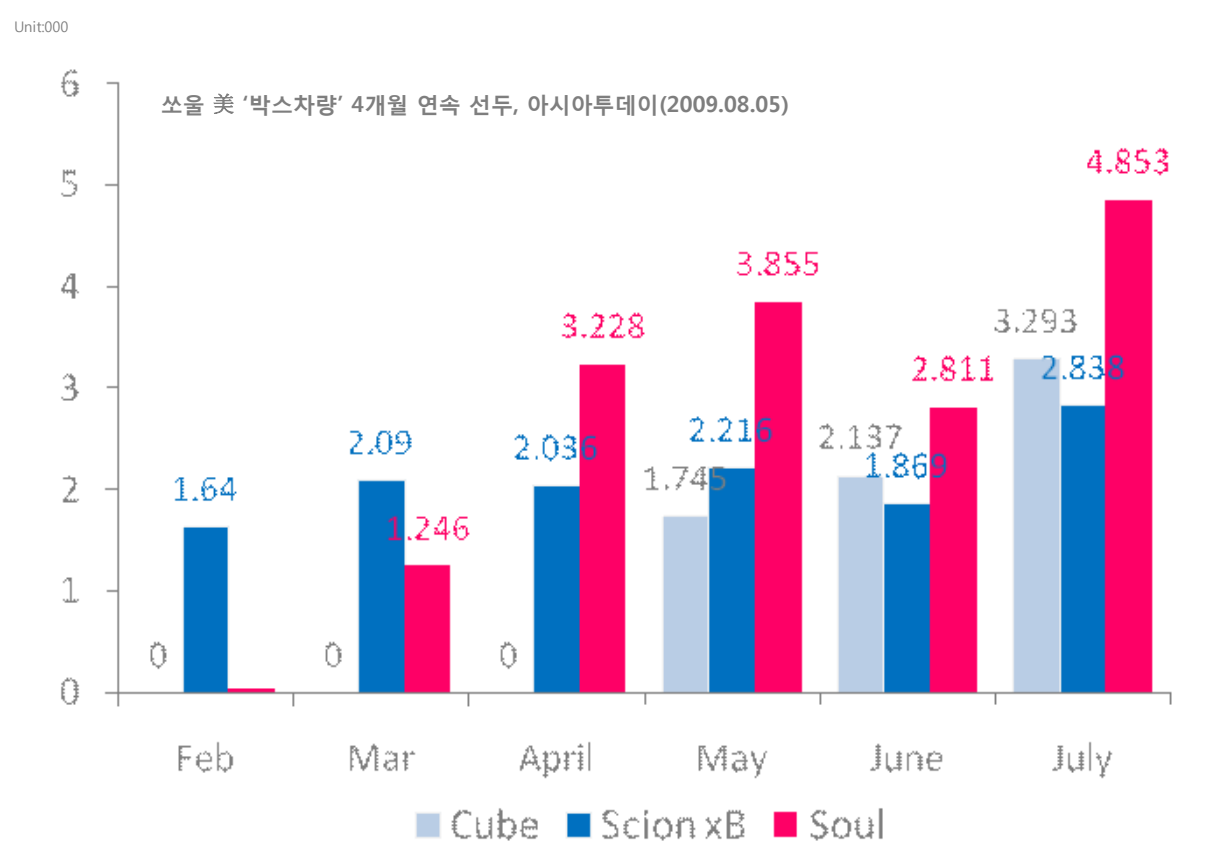

기아자동차 SOUL의 혁신적인 제품전략 - 소비자의 soul을 움직이다 - 163 
(약 1750만원)로 싸이언 xB보다는 싸지만, 큐브 보다는 비싸 단순한 가격 경쟁력 만으로는 이 와 같은 인기를 설명하기 힘들며, 차량의 혁신성, 품질과 같은 제품 특성 및 마케팅 전략의 총체적 인 결실이라 할 수 있을 것이다(〈그림 12〉 참고). 기아자동차는 SOUL과 각종 신차들의 판매 호조로 국내 산업수요 정체 상황 속에서도 전 년판매량 대비 $24.6 \%$ 증가한 19 만 2천대를 판 매함으로써 국내 시장점유율이 $25 \%$ 에서 $31 \%$ 로 높아졌다. 또한 전 세계적인 경기침체의 영 향으로 산업수요가 대폭 감소한 미국(-35\%), 유럽 $(-11 \%)$ 등의 시장에서도 선전함으로써 시 장점유율이 미국은 $3.1 \%$, 유럽은 $1.6 \%$ 상승했 다. 이와 같은 기아자동차의 성장에 SOUL의 성공이 주요한 역할을 한 것으로 평가된다. 지 금까지의 성과를 평가해 볼 때, SOUL의 신제 품 개발 및 출시 전략은 성공적이었으며, 앞으 로 사후 관리를 통한 제품 및 서비스에 대한 보완 및 개선이 이루어진다면 더욱 좋은 성과 를 기대할 수 있을 것이다. '차급을 초월한 블루 오션을 개척하여 판매 볼륨의 증대를 가져오며, 기업 이미지를 제고시킨다'는 목표는 지금까지 성과를 볼 때 성공적으로 달성된 것으로 평가 된다. SOUL의 성공은 디자인 혁신을 통한 기 아자동차(주)의 초일류 기업으로의 도약을 위한 첫걸음을 성공적으로 디딘 것이라 하겠다.

〈논문 접수일: 2009. 09. 30〉

〈게재 확정일: 2009. 09. 30〉

\section{참고문헌}

김태우(2008), 미코노미, 한빛미디어

하송 (2008), 디자인의 진화와 기업의 활용전략, 삼성경제연구소

C. Bowman and D. Faulkner (1990), Competitive and Corporate Strategy, Irwin

David A. Aaker (2007), Strategic Market Management, Wiley

Kim, W. C. and R. Mauborgne (2005a), Blue ocean strategy, Boston: Harvard Business School Press

Kim, W. C. and R. Mauborgne (2005b), Value innovation: a leap into the blue ocean, Journal of Business Strategy, Vol.26, No.4, pp.22-28. 


\title{
Innovative Product Strategy of KIA SOUL - Attract customers' soul -
}

\author{
Lee, Doo-Hee* \\ Lee, Jong-Ho** \\ Jeon, Ki Heung***
}

\begin{abstract}
The objective of this case study is to analyze how effectively KIA SOUL, which is a leading Crossover Utility Vehicle (CUV) brand, has created a new market space through innovative product strategy. Up until now, most car manufacturers have focused only on the traditional product market segments missing out on the opportunity of the crossover segment market. KIA SOUL found a new market space by identifying the high crossover utility demand and filling the gap between the current product category values and the emerging crossover product category values. This case study illustrates that an innovative product strategy can be effectively employed to create a new market space in the saturated car manufacturing industry.

The case summarizes that the innovative product strategy of KIA SOUL is comprised of four primary pillars: design innovation, market frontier in CUV, the first company to launch customizing service brand-TUON, and functional innovation. The KIA SOUL case study provides valuable insights and implications for many other companies that are planning to find "blue oceans" for their own business.
\end{abstract}

Key words: innovative product strategy, design management, blue ocean

* Professor, Korea University Business School, Korea University

** Corresponding Author, Assistant Professor, Korea University Business School, Korea University

*** Associate Professor, School of Business Administration, Jeonju University 